\title{
nature
}

10 May 2001 Volume 411 Issue no 6834

\section{Time for a bipartisan OTA}

The US legislature is bereft of objective guidance on issues that underpin much of its work. A congressional Office of Technology Assessment should be reinstated as soon as possible, on a solid basis of bipartisan support.

W hen the US Congress abolished its Office of Technology Assessment (OTA) back in 1995, there was much talk of the most powerful legislature in the world obtaining advice on technical and scientific issues from "a multiplicity of sources" elsewhere. These sources, it was claimed, would provide the variety of perspectives necessary for Congress to deal with the complex scienceand technology-based issues that fall under its jurisdiction.

Unsurprisingly, perhaps, nothing akin to this has materialized. The OTA has left a vacuum, as its defenders said it would. In the six years since it disappeared, difficult science-based issues continue to confront the legislature - global warming, transgenic crops, the alleged energy crisis and embryonic stem-cell research, to name but a few. The OTA was meant to provide an objective assessment of these kinds of issues. What Congress receives instead is a deluge of information from outside sources, mostly biased, some of it masquerading as independent.

The OTA was established in 1973 to help harassed congressmen and -women - and, yes, many of them do work 18-hour days, whatever it says in the movies - and their non-specialist staff to digest information on issues that are inherently complex. Unfortunately for this ideal, the OTA operated during a period in which the Democrats controlled the House all of the time and the Senate almost all of the time. Frustratingly for the OTA's ambitions to establish a non-partisan reputation, it was acting as a counterweight to a Republican administration in the White House for all but four of these years.

It is no wonder that at the end of that time, the agency had become associated with a Democrat agenda in the minds of some Republicans. Additionally, when the Republicans took control of Congress in 1995 with a radical government-cutting agenda, they soon discovered that it was almost impossible to close down any component of the US government, and picked on their own scientific brains trust as just about the only thing they could shut. It was a foolish decision, resisted at the time by some Republicans who knew the OTA well, such as Amo Houghton (Republican, New York), and regretted now by others.

A modest effort is under way to prepare the groundwork for the revival of something similar to the OTA. Academics and former staff of the office will meet in Washington on 14 June to discuss a strategy for this.

But great care will required if anything is to come of this effort. The most important challenge is to win the confidence of a substantial body of Republicans in any proposed model. There are idealogues in Congress who will have no appetite for an instrument such as the OTA, however objective and efficient it may be. But they are not in the majority in either body of Congress, and their hostility should not discourage steps to revive the agency.

On the contrary, a technology-assessment office should be revived now, on a truly bipartisan basis. Allies of the concept may be tempted to bide their time, aware that there is a good chance that the Democrats will regain control of the House and Senate next year. Such a delay would be a lost opportunity. A small, dynamic and politically neutral office established now - while Republicans control Congress would stand a better chance of avoiding the fate of the last one.

\section{An end to procrastination?}

A new German bioethics council should lead to a prompt resolution of debates over stem cells.

G ermany's main grant-giving agency, the Deutsche Forschungsgemeinschaft (DFG), is proposing a muchneeded relaxation of the country's restrictive embryo protection law, which bans the cultivation of human stem-cell lines from embryo cells. In doing so, it crosses swords with a hostile government whose position on the sanctity of embryonic cells appears unshakeable (see page 119).

Coincidentally, Chancellor Gerhard Schröder has created a national ethics council to advise the government on bioethics (see page 124). Stem-cell research will be its baptism of fire, and could be a precedent for how Germany handles future ethical dilemmas in basic research.

The DFG has not rushed its thinking on human embryonic stemcell research. It has taken due time to consider the issue thoroughly, and has reached fair and balanced conclusions. Its suggestion that, in well-justified cases and with appropriate checks and controls, researchers should be allowed to import and even to cultivate human embryonic stem-cell lines is a reasonable response to recent scientific advances. These advances increasingly indicate the medical potential of stem cells to replace diseased tissues and organs.
It is true, of course, that the DFG's position is driven by the interests of the scientific community. But this does not mean that such interests are inevitably different from those of society, which will probably not want to miss out on any medical benefits that might arise.

Appropriately and inevitably, German citizens want any move towards the use of humans - including the helpless embryo - for research purposes to be discussed in depth. Soul-searching debate on embryonic stem-cell research has filled newspapers and spawned a stream of bioethical conferences over the past two years. The DFG has held back from endorsing the research, arguing for its restriction to adult stem cells until the weight of scientific information justified crossing a new boundary - as it now believes is the case.

But when does society's wider debate end? The government's demand for it to continue smacks of fear of taking a tough decision the year before a general election. Hopefully, the new national ethics council will not feel the need to start from scratch, or unduly delay reporting its conclusions. As Germany learnt to its cost in gene sequencing, late entry to a fast-moving research field leaves the research community and others at a significant disadvantage. 